\title{
Is Parent Abuse a Form of Domestic Violence?
}

\author{
Paula Wilcox \\ School of Applied Social Science, University of Brighton \\ E-mail: P.S.Wilcox@brighton.ac.uk
}

There is a lack of research on parent abuse in the UK and a lack of research on the overlap between domestic violence and parent abuse internationally. This article explores why this is the case. Findings suggest that conceptual conflicts in defining both concepts, in framing children's safety as subsumed under mothers' safety and the desire to challenge deterministic 'cycle of violence' models may unwittingly have contributed to the failure to address parent abuse in the domestic violence field. The author argues that only by integrating parent abuse into the domestic violence framework will this issue be appropriately addressed.

Keywords: Parent abuse, domestic violence, children.

\section{Introduction}

It's one of the biggest taboos in family life. It happens - we know that - but no one talks about it. And there's really no one to talk to about it - mothers (who are most often on the receiving end) don't tell their friends and there isn't the network of support organisations to help you deal with it the way there are for women battered by partners. (Hilary Chamberlain, Parentline Plus, cited in Lewis, 2009)

Parent abuse is a highly sensitive issue since it not only disrupts the usual direction of power relations from parent to child, but stigmatising 'bad parent' discourses are commonplace, making parent abuse virtually a taboo subject (Edenborough et al., 2008). Moreover, there are powerful intrapersonal and interpersonal psychosocial and sociocultural processes of silencing involved which make it hard for family members as well as professionals to effectively raise and then challenge parent abuse.

In the same way that domestic violence was a hidden issue until feminist research and activism exposed its incidence and prevalence in the 1970s, so parent abuse is a hidden issue today. Indeed, parent abuse is one of the most unexplored and under-theorised forms of family violence in the UK. In a cultural context where young people are frequently vilified, the tensions around conceptualising and responding to young people who may have been victims of domestic violence as well as victimisers (Gallagher, 2004a, b) are acute. Whilst there is a paucity of research on parent abuse, evidence suggests that the abuse of mothers often emerges in situations where there have been other forms of family violence (Hunter et al., 2010), particularly towards the mother by a male partner (Bobic, 2002; Cottrell and Monk, 2004; Daly and Nancarrow, 2009). This raises important issues around the links with domestic violence and the influence of gendered power relations in parent abuse.

The aim of this article, therefore, is to explore the question: 'Is parent abuse a form of domestic violence'? In order to do this, it will examine what we know about parent abuse 
from the international literature and examine the relative neglect of parent abuse in the UK. It will look at the way in which children's safety has been framed in the domestic violence field and the implications this has had for current policy and practice. It will argue that parent abuse needs to be integrated into the domestic violence framework in order for it to be appropriately addressed. In looking at these issues, this paper seeks to open up new avenues for the future direction of policy and practice in the domestic violence field.

\section{Defining parent abuse}

Children's abusive behaviour towards parents is often constructed as an individualised medical, behavioural or criminal problem of the child. Interventions, therefore, focus on the child him/herself rather than the parent/child relationship and tend to ignore structural influences such as the social construction of gender. The literature reveals (see further Hunter and Nixon, Introduction to this volume) that a range of terms are used in attempting to capture this phenomenon; practitioners tend to use child-to-parent violence (Gallagher, 2004a, b), whereas academics tend to use parent or mother abuse (Cottrell, 2001; Robinson et al., 2004; Hunter et al., 2010). Definitions of such abuse usually focus on a limited range of physical behaviours such as hitting (Paulson et al., 1990; Browne and Hamilton, 1998), although other forms of violence are identified as important including abusive verbal behaviours often arising from young people's (especially young men's) belief in entitlement outweighing responsibilities (Jenkins, 1990).

The term 'abuse' is useful in that it reflects the nature of the behaviour and correctly locates the phenomena within the wider field of familial abuse (e.g. domestic abuse, elder abuse, child abuse). The use of 'violence' alone reinforces the idea that parental abuse is solely about physical violence and ignores the multiplicity of behaviours occurring within a range of familial relationships. A more nuanced definition is needed that differentiates between the challenging behaviour that may fall within the norms of adolescent responses and that considered abusive. This article supports taking a selfdefined approach to defining parent abuse, which argues that adolescent/children's behaviour should be considered violent or abusive 'if others in the family feel threatened, intimidated or controlled by it and if they believe that they must adjust their own behaviour to accommodate threats or anticipation of violence' (Paterson et al., 2002: 90).

\section{The extent of parent abuse}

Even in the international sphere, knowledge of the extent of parent abuse is limited and frequently comprises self-report studies with adolescents who may minimise the rate and severity of their violence (Cornell and Gelles, 1982; Peek et al., 1985; Agnew and Huguley, 1989). Gallagher's (2008) review of the literature reveals that mothers are up to five times more likely to be victims of parent abuse than fathers. This chimes with knowledge of the extent and direction of domestic violence more generally, since, although some women are violent to men, and abuse occurs in some same-sex relationships, historically, statistically and globally the predominant pattern is one of men's violence towards women (Dobash and Dobash, 1992; Morley and Mullender, 1994).

A UK survey of 30,000 telephone calls received from October 2007 until June $2008^{1}$ found that 17 per cent discussed adolescents' (mostly thirteen to fifteen years 
old) challenging verbal aggression and a further 8 per cent discussed their physical aggression. The incidents described were usually targeted at mothers who often felt 'desperate, isolated, helpless, ashamed and out of control' (Parentline Plus, 2008: 6). It was mothers who more frequently reported aggressive behaviour, with 66 per cent of long calls discussing verbal aggression (8 per cent from fathers) and 84 per cent of long calls discussing physical aggression (8 per cent from fathers) (Parentline Plus, 2008: 10).

This survey indicates that there are gendered patterns of violence in parent abuse and little is known about the reasons for this; however, ideas around violent or hyper masculinity, the lower status of women in our culture and the fact that women are more likely to take primary responsibility for children are important factors to be explored (UN, 2010). Importantly, children who perpetrate parent abuse may have witnessed their mother being abused by their father/male partner (Gallagher, 2008; Holt, 2009b) and such mothers are more likely to feel guilty for failing to stop the violence (Hunter et al., 2010). At present, it is impossible to state with any accuracy the extent to which domestic violence and parent abuse overlap as parent abuse is not recorded as a form of domestic violence.

\section{Explaining domestic violence}

For centuries women's safety in the home was neglected and it was only due to tireless work by feminists from the 1970s that domestic violence gained a place on the policy agenda. The women's refuge movement was established over this period as women's groups uncovered the extent of domestic violence experienced by women and realised that there was little support and nowhere to escape to other to than informal supporters (Hanmer and Saunders, 1984; Dobash and Dobash, 1979, 1992). Feminist work against all forms of violence against women brought a new discourse on male violence against women into the public arena, providing 'a vehicle for change', a significant shift in the gender order and improved services for domestic violence victims/survivors from a range of social agencies. Domestic violence was clearly defined in feminist research as violence against women by husbands and male intimate partners and ex-partners (Dobash and Dobash, 1979, 1992; Bograd and Yllö, 1988).

The move from feminist discourse on domestic violence to public discourse brought new dilemmas and contradictions in this field as feminist understandings butted against age-old, traditional discourse on domestic violence which justified and minimised male violence, as well as academic perspectives on domestic violence which challenged the conceptualisation of domestic violence as violence against women from adult male ex/partners (for example Renzetti and Miley, 1996). Family systems researchers (Straus et al., 1980) conceptualised domestic violence as an aspect of dysfunctional family dynamics, adopting a broader definition of the term to include violence in all family relationships using the term 'spouse abuse' or 'intimate partner violence' to refer more specifically to violence in sexual relationships (Straus et al., 1980). Family violence researchers, therefore, rejected the gendered perspective of feminists, adopting instead a gender blind approach. It became clear that a gendered definition of domestic violence excluded those who did not fit the model of the (heterosexual female) sufferer and the (heterosexual male) perpetrator and from the late 1990s to 2000s, research on same-sex domestic violence also challenged a feminist definition of domestic violence that was exclusive to heterosexual relationships (Renzetti and Miley, 1996; Donovan et al., 2006 
amongst others). More recently, research on so-called honour violence also challenged the heterosexual definition, arguing domestic violence includes violence by other family members (Welchman and Hossain, 2005; Gill, 2008).

By the 2000s, definitions of domestic violence used in UK policy documents tended to broaden in response to the challenge to encompass not only a wider range of victims (e.g. elder abuse, same-sex abuse, 'honour' violence) but also a wider range of violence than physical assault (in particular psychological abuse). As the conceptual and political battles over the term domestic violence continued to rage during this time, many feminists and pro-feminists moved away from the domestic violence concept and towards a concept of violence against women. ${ }^{2}$ Violence against women recognises domestic violence as just one form of violence amongst others that are experienced by women which are predominantly perpetrated by men. However, even in recent UK policy documents, violence towards women/parents by their children is not recognised as domestic violence (Hunter et al., 2010).

\section{Explaining children's experiences of domestic violence}

No one thinks enough of the kids - thinks what effect it has on them. It doesn't just affect the mother - it's the kids... Because they're the ones that have got to see it, and hear it (17 year old girl cited in Humphreys and Mullender, 2002: 5).

There is now a growing body of international literature detailing children's experiences of domestic violence revealing the extent to which children are involved in, and harmed by, witnessing domestic violence whether or not there are physical injuries (Abrahams, 1994; Humphreys and Mullender, 2004; Holt et al., 2008). In 40-70 per cent of cases where women are being abused, children are also being directly abused (Bowker et al., 1988; Stark and Flitcraft, 1996). In England and Wales, the Department of Health estimates that at least 750,000 children a year witness domestic violence and nearly three quarters of children on the 'at risk' register live in households where domestic violence occurs (2002: 16). This evidence of the extent of children's involvement in domestic violence makes it vital to further examine the links between domestic violence and parent abuse.

In the same way that the domestic violence field was fraught with competing discourses, so the development of policy and practice on children's experiences of domestic violence has also been a site of competing discourses and hence differing policy and practice interventions. An average of two women a week are killed by their male (ex)partner in England and Wales and the highest risk of danger occurs when women leave a domestic violence relationship (Povey, 2005). Due to the acute dangers faced by women and children fleeing from domestic violence, the safety of women and children has always been the highest priority for workers/volunteers in the refuge movement. As a result, when we turn to look at children's safety, refuge workers have always seen this as inextricably linked with their mother's welfare. The underlying model is that children are better protected when their mother is properly supported and protected (Horner, 2008; Douglas and Walsh, 2010). This remains a keystone idea of the refuge movement, as research reveals that domestic violence in heterosexual relationships is often targeted not only at the woman but also at the 'mother-child' relationship (Wilcox, 2006). 
Mezey and Bewley (1997) reviewed research in this area, highlighting the dangers to women and unborn children. Domestic violence may commence or escalate around decision making on whether to have children or not (Wilcox, 2006) and during pregnancy (Hillard, 1985; Bohn, 1990; Stewart and Cecutti, 1993; Wilcox, 2006). Two per cent of women surveyed in GP waiting rooms in Hackney reported a miscarriage they believed to have been caused by a violent partner (Stanko et al., 1998) and after giving birth is a period of greatest risk to the mother of moderate to severe violence (Gielen et al., 1994).

On the other hand, however, seeing children's safety as being subsumed within the mother's safety has arguably had some negative effects; for instance, it has tended to obscure the separate needs of children who experience domestic violence. Feminist thinkers today, therefore, whilst insisting on retaining the centrality of the mother's safety, would recognise the importance of simultaneously acknowledging, and acting on the knowledge that children's needs are not always the same as those of their mothers (Bagshaw and Chung, 2001; Powell and Murray, 2008).

A further area of conflict which impacted on children as well as mothers/parents arose over the adoption of the 'cycle of violence' model ${ }^{3}$ (Walker, 1979). This was especially influential in courts in the USA, but also gained some influence in the UK during the 1980s. The most influential idea from the 'cycle of violence' thesis was that children who experience domestic violence will go on to become abusers themselves, with boys more likely to become perpetrators and girls to become victims (Women's Aid, 2007). Not surprisingly, this idea raised intense concern in the anti-domestic violence movement due to the negative implications of accepting this deterministic model, which encouraged young people (and their parents) to believe they would inevitably become future aggressors or victims (Humphreys and Mullender, 2002: 17). Moreover, child protection professionals would be led to believe such young people to be a 'bad bet' when they become the partners and parents of the future (Humphreys and Mullender, 2002: 26). The 'cycle of violence' model and research in this area was subjected to stringent criticism as a result (see, for example, Stark and Flitcraft, 1985). Morley and Mullender (1994) point out that although studies suggest a possible inter-generational pattern, this should not be automatically assumed as no study shows 100 per cent of adult perpetrators or victims of domestic violence as having had experiences of violence in their childhood, and many report fewer than 50 per cent with this correlation (see, Barker, this volume).

Today there is more awareness of the individual needs of children and Women's Aid focuses on making safe arrangements for children, stressing that children are individuals who respond to domestic violence differently. The Survivors Handbook for example has a section on 'when children become aggressive' (Women's Aid, 2009) and 'The Hideout', which is the Women's Aid web space for children which says:

Will children or young people grow up to become an abuser? Many children and young people who grow up with domestic violence in their homes are afraid that they will also become an abuser or a victim of domestic violence. This does not have to be true! There are many, many children and young people who grow up in homes with domestic violence and do not turn into abusers or victims themselves. (http://www.thehideout.org.uk/under10/ adults/effectonchildren/default.aspa [accessed 28/7/2011])

On the page for adults trying to find out about the impact of domestic violence on children, Women's Aid gives advice that 'Each child/young person will respond differently 
to trauma and some may be resilient and not show signs of any negative effects', going on to describe some possible effects from a Royal College of Psychiatrists briefing (2004), including anxiety or depression, difficulty sleeping, nightmares or flashbacks or may complain of physical symptoms such as tummy aches, bed wetting and temper tantrums. 'They may have ambivalent feelings towards both the abuser and the non-abusing parent' (http://www.thehideout.org.uk/under10/adults/effectonchildren/default.aspa [accessed 27.07.2011]).

Without doubt it is very important that children do not see themselves as inevitably going on to become either victims or perpetrators of abuse and violence because they have experienced domestic violence in their family. However, while there may not be a proven, causal connection, there are undoubtedly families where following domestic violence there is also parent abuse. So the playing down or denial of the link between DV and parent abuse may be problematic. Firstly, it is very difficult for such parents to find out where to get information and appropriate support with abuse and violence from their children. Secondly, de-emphasising possible links between domestic violence and future abuse of parents may indicate to a parent that this response is very rare and we do not know whether this is the case. Thirdly, the relative silence may intensify the stigma experienced and encourage parents not to disclose the abuse happening to them. This approach with all good intentions may unwittingly distort the nature and extent of adolescent child to parent abuse and violence. It is not that parent abuse is not recognised or acknowledged, but as those working in the field say, 'parent abuse is acknowledged, but it is dealt with almost tentatively due to the limited knowledge or experience of those dealing with the disclosures' (personal communication from former specialist DV worker 2010). However, for those suffering parent abuse this approach may be contributing to the failure to give them a voice, thus increasing their isolation and stigmatisation.

\section{Should parent abuse be conceptualised as a form of domestic violence?}

For the past two or three years I suffered severely. I was verbally abused, hit and kicked and I was afraid of him. In fits of rage and anger he would hurt me and cause damage to my home. He was a violent, abusive and angry person who would not do anything he was told and could not take 'no' for an answer. When he didn't get what he wanted, especially money, he would start abusing me and get stuck into me. He was like a person possessed. Anna, a single mother, describing the behaviour of her fifteen-year-old son, Mark. (Gallagher, 2004a: 1)

Reading Anna's quote above highlights how closely descriptions of parent abuse chime with descriptions of DV. Indeed, there are many similarities between domestic violence and parent abuse since both entail a constellation of abusive behaviours embedded in the family relationship. In both cases, the majority of victims/survivors are females/mothers. Both involve a continuing process of social harm (rather than 'one-off' events) requiring day-to-day management (Holt, 2009b). As with domestic violence, parent abuse involves everyday stresses which shape a parent's ability to 'parent effectively' (Ghate and Hazell, 2002; Holt, 2009). These stresses in both cases frequently entail the physical withdrawal and psychological isolation from other family members (Holt, 2009). This would indicate the need in cases of parent abuse (as with domestic violence) to put in place holistic, multi-agency approaches offering choices of response to both parent/mother and child. 
Specialised domestic violence services already work in this way and are qualified to deal with such cases.

On the other hand, it is important to distinguish between parent abuse and intimate partner abuse because they differ in a number of respects. The parent has an ongoing responsibility to parent, making the option of ending or leaving the relationship inappropriate. Also, although parents who are victimised may not be more powerful physically than the 'abusing' child, they are potentially more powerful in terms of access to resources. Counteracting this, however, is the fact that a child's threats of or actual physical violence, or of taking life-threatening risks, are behaviours which exert power over parents. In particular, single mothers who have ended a violent relationship experience feelings of guilt and blame more acutely (Ambert, 1999) and this makes them more vulnerable to such behaviours.

Conceptualising parent abuse as a form of domestic violence would require a change in current social policy. The New Labour government in the National Domestic Violence Delivery Plan defined domestic violence as 'any incident of threatening behaviour, violence or abuse (psychological, physical, sexual, financial or emotional) between adults who are or have been intimate partners or family members, regardless of gender or sexuality'4 (Home Office, 2005). This definition of domestic violence not only excluded violence from adults to children but also excluded violence to adults from children (parent abuse). Contemporaneously, the government tackled young people's behavioural problems mainly through the youth justice system and parenting orders (see Condry and Miles and Hunter and Piper, this volume). This is very problematic, in particular the positioning of the parent as a 'victim' in relation to her/his child, the increased criminalisation of adolescent behaviour and the potential for an adversarial intervention into family life (Holt, 2009).

The current UK government has adopted a violence against women approach in addressing domestic violence (Cabinet Office, 2011) and an opportunity to consider the embedding of parent abuse within a domestic violence framework may be possible since, following a recommendation from the Home Affairs Committee report in 2008, the government will be consulting on a revised definition of domestic violence to include victims under eighteen years of age (Cabinet Office, 2011: 30) and it would seem a logical extension of this to include perpetrators under eighteen and to identify parent abuse as a form of domestic violence.

In practice terms, there would be clear advantages to conceptualising parent abuse as another form of domestic violence since the dominant definition of domestic violence has broadened to include a wider range of victims and forms of violence. This would immediately link parent abuse into existing multi-agency networks with expertise of multiple forms of family violence. Domestic violence agencies would be well qualified to counter the currently prevalent culture of 'mother blaming' (Caplan, 1986; LaddTaylor and Umansky, 1997) which has been widely documented in relation to dominant explanations of youth offending, in particular focusing on 'working-class mothers' (Griffin, 1993) and 'single mothers' (Mann and Roseneil, 1994).

\section{Indicating the way forward}

Taking this issue forward will not be easy, however, since studies on general populations of children and young people have revealed a worrying degree of tolerance of violence 
against women (Burton et al., 1998; Burman and Cartmel, 2004; Laville, 2011, McCarry, 2010; Barter et al., 2009) and currently domestic violence services are being subjected to cuts in funding (Salmon, 2011). Verbal intimidation, abuse and misogyny are frequently treated as the norm in many school playgrounds and can be seen as the beginning of a continuum of abuse suffered by girls and young women (Laville, 2011). Recently, Keir Starmer, the Director of Public Prosecutions, has said that teenage girls between sixteen and nineteen are now the group most at risk of DV, closely followed by girls aged twenty to twenty-four, victims of younger abusers who are in their teens and early twenties, suggesting that primary prevention work in schools and elsewhere must be an important focus for change.

Gender-sensitive approaches will be essential as it is apparent that the increased regulation of parenthood by the state is highly gendered. A small emerging body of work is beginning to evidence the disproportionate impact ASB interventions have had on women-headed households; for example Hunter and Nixon's (2001) work on evictions from social housing illustrates the ways in which mothers are expected to take the blame and express remorse for the behaviour of their children, in a way which is not applied to fathers. Studies reveal that Parenting Orders are almost always given to mothers (Gelsthorpe, 1999; Holdaway et al., 2001; Henricson, 2003). This is seen by mothers as grossly unfair and unjust as their child committed the offence and in their view should be held responsible (Holt, 2009a). Within this gendered parenting/mothering discourse, there is no space for the mother to be constructed as a 'victim' of the child's violence; instead she is seen as failing to exercise proper parental control and, therefore, is portrayed as irresponsible and to blame.

\section{Conclusions}

Knowledge of the extent of parent abuse is limited and reviews of the literature reveal that mothers are more likely to be victims of parent abuse than fathers as with the extent and direction of domestic violence more generally. These silences around parent abuse are under-explored and this article has analysed the history of anti-domestic violence work and of children's experiences of domestic violence to consider whether these have contributed towards the silences on parent abuse. As with other forms of family violence, silences around parent abuse are also engendered by family members who censor and silence themselves, feeling stigmatised by dominant 'bad parent' discourses. Exploration of parents' perceptions of being abused by their children needs much further exploration in order to theorise parent abuse in the family setting. New developments are under way, for example, in Brighton and Hove under the Break4Change programme (Munday, 2009; http://break4change. blogspot.com/2009/04/why-break4change-blog.html [accessed 28.07.2011]) which works with young people and parents in parallel groups using creative communication techniques.

Much more research is also needed in the field on how domestic violence influences child development and the development of prevention and intervention programmes for children and parents. The article has suggested that feminist work, due to the scale of violence against women, has understandably focussed on women as victims/survivors of domestic violence in heterosexual relationships, prioritising the safety of women; children's safety consequently tended to be subsumed as dependent on mothers' safety. 
As a result, however, children's own separate needs were not always fully recognised. In the robust rebuttal of the 'cycle of violence' model, the potential for children to have ambivalent feelings towards both the abuser and the non-abusing parent was underplayed and these factors have contributed to the relative lack of attention to parent abuse in the domestic violence field and may contribute to the further silencing of family members.

Turning to the question 'is parent abuse a form of domestic violence?', the author has highlighted some of the dilemmas faced by professionals in the domestic violence field in responding to parent abuse. Nevertheless, the argument has been made that parent abuse should be viewed as a form of domestic violence. Key issues for those involved with domestic violence in the UK are raised on the need to resolve conceptual conflicts over defining parent abuse, challenge tentative approaches to parent abuse, address lack of knowledge, information and training on parent abuse, carry out further research into children's responses to experiencing domestic violence and to improve domestic violence organisations' access to funding and other resources. From the 1970s, many brave victims and survivors broke the silence surrounding domestic violence in heterosexual and samesex relationships as well as other violences in family relationships - it is now time to break the silence on parent abuse.

\section{Notes}

1 Parentline Plus, now called Family Lives, is a charity offering support to those caring for children.

2 The influence of feminists working with the UN to have violence against women recognised as a human rights abuse was very important in this move towards a violence against women framework (Bunch, 1995).

3 This concept refers to two separate models of domestic violence and this is both confusing and misleading. The first model claims that 'abuse carries on to the next generation' and the second that a 'cyclical model of abuse (is) followed by remorse' (Women's Aid, 2007). In Women's Aid's view, 'neither of these models is particularly helpful in explaining domestic violence, as they are deterministic, not generally applicable, and tend to remove responsibility for the violence from the perpetrator' $\mathrm{http}: / / \mathrm{www}$.womensaid. org.uk/domestic-violence-articles.asp?section $=00010001002200410001$ \&itemid=1279 [accessed 28/7/ 2011] (emphasis in original).

4 This definition recognises domestic violence in same-sex relationships and an adult is defined as any person aged eighteen years or over. Family members are defined as mother, father, son, daughter, brother, sister and grandparents, whether directly related, in laws or stepfamily. Domestic violence is acknowledged as occurring across society regardless of age, gender, race, sexuality, wealth and geography.

\section{References}

Abrahams, C. (1994) Hidden Victims: Children and Domestic Violence, London: NCH Action for Children.

Agnew, R. and Huguley, S. (1989) 'Adolescent violence towards parents', Journal of Marriage and the Family, 51, 699-711.

Ambert, A. (1999) 'The effect of male delinquency on mothers and fathers: a heuristic study', Sociological Inquiry, 69, 4, 621-40.

Bagshaw, D. and Chung, D. (2001) 'The needs of children who witness domestic violence: a South Australian study', Children Australia, 26, 3, 9-17.

Barter, C., McCarry, M., Berridge, D. and Evans, K. (2009) Partner Exploitation and Violence in Teenage Intimate Relationships, London: NSPCC.

Bobic, N. (2002) Adolescent Violence Towards Parents: Myths and Realities, Marrickville, NSW: Rosemount Youth \& Family Services. 
Bograd, M. L. and Yllö, K. (1988) Feminist Perspectives on Wife Abuse, Thousand Oaks, CA: Sage.

Bohn, D. (1990) 'Domestic violence and pregnancy: implications for practice', Journal of Nurse Midwifery, $35,19-21$.

Bowker, H., Arbittell, M. and McFerron, J. R. (1988) 'On the relationship between wife beating and child abuse', in K. Yllo and M. Bograd (eds.), Feminist Perspectives on Wife Abuse, Thousand Oaks, CA: Sage.

Browne, K. D. and Hamilton, C. E. (1998) 'Physical violence between young adults and their parents: associations with a history of child maltreatment', Journal of Family Violence, 13, 1, 59-79.

Bunch, C. (1995) 'Transforming human rights from a feminist perspective', in J. Peters and A. Wolpers (eds.), Women's Rights, Human Rights: International Feminist Perspectives, New York: Routledge.

Burman, M. and Cartmel, F. (2004) Young People's Attitudes towards Gendered Violence, http://www.healthscotland.com/uploads/documents/GenderedResearch.pdf [accessed 28.07.2011].

Burton, S., Kitzinger, J., Kelly, L. and Regan, L. (1998) Young People's Attitudes towards Violence, Sex and Relationships, Edinbugh: Zero Tolerance Charitable Trust.

Cabinet Office (2011) Call to end Violence against Women and Girls: Action Plan, 30, http://www.homeoffice.gov.uk/publications/crime/call-end-violence-women-girls/vawg-actionplan?view=Binary [accessed 28/7/2011].

Caplan, P. J. (1986) 'Take the blame off mother', Psychology Today, 20, 10, 70-1.

Cornell, C. P. and Gelles, R. J. (1982) 'Adolescent-to-parent violence', The Urban Social Change Review, $15,1,8-14$.

Cottrell, B. (2001) Parent Abuse: The Abuse of Parents by Their Teenage Children, Ottawa: Health Canada.

Cottrell, B. and Monk, P. (2004) 'Adolescent-to-parent abuse: a qualitative overview of common themes', Journal of Family Issues, 25, 1072-80.

Daly, K. and Nancarrow, H. (2009) 'Restorative justice and youth violence toward parents', in J. Ptacek (ed.), Restorative Justice and Violence against Women, Oxford: Oxford University Press.

Department of Health (2002) Women's Mental Health: Into the Mainstream - Strategic Development of Mental Health Care for Women, http://www.dh.gov.uk/assetRoot/ 04/07/54/87/04075487.pdf [accessed 28.07.2011].

Dobash, R. E. and Dobash, R. P. (1979) Violence against Wives: A Case against the Patriarchy, London: Open Books.

Dobash, R. E. and Dobash, R. P. (1992) Women, Violence and Social Change, London and New York: Routledge.

Donovan, C., Hester, M., Holmes, J. and McCarry, M. (2006) Comparing Domestic Abuse in Same Sex and Heterosexual Relationships, http://www.broken-rainbow.org.uk/ cohsar_report.pdf [accessed 28.07.2011].

Douglas, H. and Walsh, T. (2010) 'Mothers, domestic violence, and child protection, violence against women', Family Law, September, 489-508.

Edenborough, M., Jackson, D., Mannix, J. and Wilkes, L. M. (2008) 'Living in the red zone: the experience of child-to-mother violence', Child and Family Social Work, 13, 464-73.

Gallagher, E. (2004a) 'Parents victimised by their children', Australian and New Zealand Journal of Family Therapy, 25, 1, 1-12.

Gallagher, E. (2004b) 'Youth who victimise their parents', Australian and New Zealand Journal of Family Therapy, 25, 2, 94-105.

Gallagher, E. (2008) 'Children's violence to parents: a critical literature review', unpublished Master of Social Work, Monash University, Australia.

Gelsthorpe, L. (1999) 'Youth crime and parental responsibility', in A. Bainham, A. Day Sclater and M. Richards (eds.), What Is a Parent? Oxford: Hart.

Ghate, D. and Hazel, N. (2002) Parenting in Poor Environments: Stress, Support and Coping, London: Jessica Kingsley Publishers.

Gielen, A., O'Campo, P., Faden, R., Kass, N. and Xue, X. (1994) 'Interpersonal conflict and physical violence during the childbearing year', Social Science and Medicine, 39, 781-7. 
Gill, A. (2008) "Crimes of honour" and violence against women in the UK', International Journal of Comparative and Applied Criminal Justice, 32, 2, 243-64.

Griffin, C. (1993) Representations of Youth, Cambridge: Polity Press.

Hanmer, J. and Saunders, S. (1984) Well Founded Fear: A Community Study of Violence to Women, London: Hutchinson.

Henricson, C. (2003) Government and Parenting: Is There a Case for a Policy Review and a Parents' Code? York: Joseph Rowntree Foundation.

Hillard, P. (1985) 'Physical abuse in pregnancy', Journal of Obstetrics and Gynaecology, 66, 185-90.

Holdaway, S., Davidson, N., Dignan, J., Hammersley, R., Hine, J. and Marsh, P. (2001) New Strategies to Address Youth Offending: The National Evaluation of the Pilot Youth Offending Teams, London: Home Office.

Holt, A. (2009a) '(En)gendering responsibilities: experiences of parenting a "young offender"', The Howard Journal, 48, 4, 344-56.

Holt, A. (2009b) 'Managing "spoiled identities": parents' experiences of compulsory parenting support programmes', Children and Society, 24, 5, 413-23.

Holt, S., Buckley, H. and Whelan, S. (2008) 'The impact of exposure to domestic violence on children and young people: a review of the literature', Child Abuse and Neglect, 32, 797-810.

Home Office (2005) Domestic Violence: A National Report, http://www.broken-rainbow. org.uk/ research/domesticviolence51.pdf [accessed 28.07.2011].

Horner, G. (2008) 'Child advocacy centers: providing support to primary care providers', Journal of Pediatric Health, 21, 1, 35-9.

Humphreys, C. and Mullender, A. (2002) Children and Domestic Violence: A Research Overview of the Impact on Children, Totnes: Research in Practice. http://www.icyrnet.net/UserFiles/mullender.pdf [accessed 14/12/10].

Humphreys, C. and Mullender, A. (2004) Children and Domestic Violence: A Research Overview of the Impact on Children, Research in Practice, http://www.icyrnet.net/ UserFiles/mullender.pdf [accessed 28.07.2011].

Hunter, C. and Nixon, J. (2001) 'Women and anti-social behaviour', Journal of Social Welfare and Family Law, 23, 4, 395-410.

Hunter, C., Nixon, J. and Parr, S. (2010) 'Mother abuse: a matter of youth justice, child welfare or domestic violence?', Journal of Law and Society, 37, 2, 264-84.

Jenkins, A. (1990) Invitations to Responsibility: The Therapeutic Engagement of Men Who Are Violent and Abusive, Adelaide, South Australia: Dulwich Centre.

Ladd-Taylor M. and Umansky L. (eds.) (1997) Bad Mothers: The Politics of Blame in Twentieth-century America, New York: New York University Press.

Laville, S. (2011) 'Teenage domestic violence: "No one did anything to stop it", Guardian Online, 16 April, http://www.guardian.co.uk/society/2011/apr/16/domestic-violence-teenage-girls [accessed 28.07.2011].

Lewis, C. (2009) 'The day my daughter hit me', The Guardian, 27 June.

Mann, K. and Roseneil, S. (1994) 'Some mothers do 'ave 'em: backlash and the gender politics of the underclass debate', Journal of Gender Studies, 3, 3, 317-31.

McCarry, M. (2010) 'Becoming a "proper man": young people's attitudes about interpersonal violence and perceptions of gender', Gender and Education, 22, 1, 17-30.

Mezey, G. and Bewley, S. (1997) 'Domestic violence and pregnancy', British Journal of Obstetrics and Gynaecology, 104, 528-31.

Morley, R. and Mullender, A. (1994) 'What do we know from research?', in A. Mullender and R. Morley (eds.), Children Living with Domestic Violence: Putting Men's Abuse of Women on the Child Care Agenda, London: Whiting \& Birch.

Munday, A. (2009) 'Break4Change: does a holistic intervention effect change in the level of abuse perpetrated by young people towards their parents/carers?', unpublished Dissertation, School of Education, University of Brighton. 
ParentlinePlus (2008) 'You can't say go and sit on the naughty step because they turn round and say make me'. Aggressive Behaviour in Children: Parents' Experiences and Needs, http://familylives.org. uk/content/aggressive-behaviour-children-parents\% E2\%80\%99-experiences-and-needs [accessed 28.07.2011].

Paterson, R., Luntz, H., Perlesz, A. and Cotton, S. (2002) 'Adolescent violence towards parents: maintaining family connections when the going gets tough', The Australian and New Zealand Journal of Family Therapy, 23, 2, 90-100.

Paulson, M. J., Coombs, R. H. and Landsverk, J. (1990) 'Youth who physically assault their parents', Journal of Family Violence, 5, 2, 121-33.

Peek, C. W., Fischer, J. L. and Kidwell, J. S. (1985) 'Teenage violence toward parents: a neglected dimension of family violence', Journal of Marriage and the Family, 47, 4, 1051-8.

Povey, D. (ed.) (2005) Crime in England and Wales 2003/2004, Supplementary Volume 1: Homicide and Gun Crime, Home Office Statistical Bulletin, No. 02/05, London: Home Office.

Powell, A. and Murray, S. (2008) 'Children and domestic violence: constructing a policy problem in Australia and New Zealand', Social Legal Studies, 17, 453-73.

Renzetti, C. and Miley, C. H. (1996) Violence in Gay and Lesbian Domestic Partnerships, New York: Harrington Park Press.

Robinson, P. W., Davidson, L. J. and Drebot, M. E. (2004) 'Parent abuse on the rise: a historical review', American Association of Behavioral Social Science Online Journal, http://aabss.org/ Perspectives2004/AABSS_58-67.pdf [accessed 28.07.2011].

Royal College of Psychiatrists (2004) Child Abuse and Neglect: The Role of Mental Health Service, http://www.rcpsych.ac.uk/files/pdfversion/cr120.pdf [accessed 13.12.10].

Salmon, S. (2011) 'How have the cuts affected domestic violence services?', 30 March, Guardian Online, http://www.guardian.co.uk/society/2011/mar/30/cuts-domestic-violence [accessed 28.07.2011].

Stanko, E., Crisp, D., Hale, C. and Lucraft, H. (1998) Counting the Costs: Estimating the Impact of Domestic Violence in the London Borough of Hackney, London: Crime Concern.

Stark, E. and Flitcraft, A. (1996) Women at Risk: Domestic Violence and Women's Health, London and New York: Sage.

Stark, E. and Flitcraft, A. (1985) 'Women-battering, child abuse and social heredity, what is the relationship?', in N. Johnson (ed.), Marital Violence, London: Routledge \& Kegan Paul.

Stewart, D. and Cecutti, A. (1993) 'Physical abuse in pregnancy', Canadian Medical Association Journal, $149,1257-63$.

Straus, M., Gelles, R. and Steinmetz, S. (1980) Behind Closed Doors: Violence in the American Family, New York: Anchor Books.

United Nations (2010), The World's Women 2010: Trends and Statistics, Chapter 6 'Violence against women', pp. 127-37, http://unstats.un.org/unsd/demographic/products/ Worldswomen/WW_full\% 20report_color.pdf [accessed 28.07.2011].

Walker, L. (1979) The Battered Woman Syndrome, New York: Springer.

Welchman, L. and Hossain, S. (eds.) (2005) Honour: Crimes, Paradigms and Violence against Women, London: Zed Books.

Wilcox, P. (2006) Surviving Domestic Violence: Gender, Poverty and Agency, London: Palgrave/Macmillan.

Women's Aid (2007) Cycle of Violence, http://www.womensaid.org.uk/domestic-violence-articles.asp [accessed 13.12.10].

Women's Aid (2009) The Survivor's Handbook, http://www.womensaid.org.uk/ [accessed 13.12.10]. 